\title{
Chemical composition and in vitro ruminal digestibility of hand-plucked samples of Xaraes palisade grass fertilized with incremental levels of nitrogen
}

\author{
F.P. Campos ${ }^{a}, *$ D.R.O. Nicácio ${ }^{b}$, P. Sarmento ${ }^{a}$, M.C.P. Cruz ${ }^{c}$, T.M. Santos $^{\mathrm{d}}$, \\ A.F.G. Faria ${ }^{d}$, M.E. Ferreira ${ }^{c}$, M.R.G. Conceição ${ }^{b}$, C.G. Lima ${ }^{e}$ \\ a Institute of Zootechny, IZ/APTA/SAA, Nova Odessa, SP 13460.000, Brazil \\ b Postgraduate program, Sustainable Animal Production, Institute of Zootechny, IZ/APTA/SAA, Nova Odessa, SP 13460.000, Brazil \\ c Department of Soils and Fertilizers, University of São Paulo, UNESP, Jaboticabal, SP 13418.900, Brazil \\ d Postgraduate program, Soil Science, University of São Paulo, UNESP, Jaboticabal, SP 13418.900, Brazil \\ e Department of Basic Sciences, University of São Paulo, FZEA, Pirassununga, SP 13635.900, Brazil
}

\section{A R T I C L E I N F O}

\section{Article history:}

Received 7 January 2015

Received in revised form

14 December 2015

Accepted 15 December 2015

\section{Keywords:}

Brachiaria brizantha

Fibre

Growing degree days

Grazing cycles

Regrowth

Tropical grass

\begin{abstract}
A B S T R A C T
Improvements in the nutritional quality of tropical grasses depend on the proper use of grazing management and nitrogen fertilization as well as climatic conditions. The aim of this study was to evaluate the effect of nitrogen $(0,125,250,375,500$ or $625 \mathrm{~kg} / \mathrm{ha}$, applied as urea), grazing cycles (GCs) and growing degree days (GDD) on the chemical composition and in vitro digestibility of dry matter (IVDMD), organic matter (IVOMD) and neutral detergent fibre (NDFD) of hand-plucked samples of Xaraes palisade grass (Urochloa brizantha cv. Xaraes). A total of 24 plots of $112 \mathrm{~m}^{2}$ each were cultivated with Xaraes palisade grass was evaluated and carried with repeated measures (GCs) and one treatment factor (N rate) in completely randomized block design, with four replications. Grass samples were collected after 26 days of regrowth from plots that were managed under rotational stocking (26 days of rest and 2 days of occupation) in six GCs (1-6). To achieve the target height of post-grazing residues $(24-27 \mathrm{~cm})$, dry Holstein cows were used with a body weight (BW) of $527 \mathrm{~kg}$ (SD $36 \mathrm{~kg}$ ), considering a consumption of $2.5 \%$ of BW and $40 \%$ estimated mass loss of pre-grazing forage. All of the nutrient concentrations were affected by $\mathrm{N}$ fertilization and GCs. The crude protein $(\mathrm{CP})$ content increased linearly with the $\mathrm{N}$ rate in each grazing cycle $(P<0.05)$. NDF decreased linearly with the $\mathrm{N}$ rate in each grazing cycle $(P<0.05)$. N fertilization increased the IVDMD, IVOMD and NDFD with a linear or quadratic response depending on the GC $(P<0.05)$. The average maximum point that was obtained in GC4 in the regression equations for IVDMD, IVOMD and NDFD as a function of $\mathrm{N}$ fertilization was $533 \mathrm{~kg} \mathrm{~N} / \mathrm{ha} /$ year. The GDD had a quadratic effect on the chemical composition and digestibility of Xaraes palisade grass with distinct $\mathrm{N}$ doses. $\mathrm{N}$ fertilization stimulated the formation of cell walls with better-quality fibre and resulted in a higher forage digestibility according to the climatic conditions and GDD. The greatest improvements in forage quality were obtained, with $\mathrm{N}$ rates greater than $382 \mathrm{~kg} / \mathrm{ha} /$ year.
\end{abstract}

(C) 2015 Elsevier B.V. All rights reserved.

\footnotetext{
Abbreviations: DM, dry matter; OM, organic matter; NDF, neutral detergent fibre assayed without a heat-stable amylase and expressed inclusive of residual ash; ADF, acid detergent fibre expressed inclusive of residual ash; EE, ether extract; CP, crude protein; NFC, non-fibrous carbohydrate; HEM, hemicellulose; CEL, cellulose; FY, forage yield; GDD, growing degree days; DD, degree days; IVDMD, in vitro digestibility of dry matter; IVOMD, in vitro digestibility organic matter; NDFD, neutral detergent fibre in vitro digestibility.

* Corresponding author. Fax: +55 1934666415.

E-mail addresses: fpcampos_99@yahoo.com, fcampos@iz.sp.gov.br(F.P.Campos).
} 


\section{Introduction}

The state that livestock production in a pasture is a major contributor to the formation of greenhouse gases (GHG) Peters et al. (2013). Nevertheless, Pessarakli (2014) reports that sustainable intensification provides significant potential to generate environmental and social benefits. For Peters et al. (2013), the preferred method of sustainability is the mitigation of GHG by increasing carbon storage in the soil, which is achieved by well-managed and fertilized pastures, which, in addition to maintaining the productivity of pasture and animal, retain water in the soil and reduce flow and erosion.

Brazil has a significant ability to reduce the emission of GHG because of its large geographic extension, areas with favourable climatic conditions and adoption of an appropriate management system (Berndt and Tomkins, 2013). This country is a major worldwide supplier of meat and milk; has the second largest herd, with 213.1 million heads; and exports of 1.9 million tons of beef (FAOSTAT, 2015). The production of Brazil is based, for the most part, on different tropical pastures. Alone, the genus Brachiaria (syn. Urochloa) occupies approximately 80 million hectares (Pessarakli, 2014), and Urochloa brizantha cv. Xaraes is among the most productive, with potential use in many tropical and subtropical countries (Nave et al., 2010). However, major constraints to cattle production in the tropics include the quantity and quality of grasses, upper grazing, use of non-adapted grasses, depletion of soil nutrients that lead to the degradation of pastures, and consequently, low animal productivity (Pessarakli, 2014).

However, the low quality of tropical forages occurs not only during periods of drought by decreased production but also during wet periods. According to Wilson and 't Mannetje (1978), $\mathrm{N}$ fertilization increases the grass yield, but over the summer (rainy season), when it is usually difficult to maintain sufficient grazing pressure to control pasture growth. The benefits of this increased yield can be partially offset by nitrogen, promoting rapid leaf senescence and decreased leaf digestibility, thereby reducing the overall pasture quality. Poppi and McLennan (1995) report that to minimize the variation of live weight gain between the rainy and dry seasons, the strategy would be to improve the length and forage quality in the rainy season.

Increasing the production and maintaining the quality of grasses are essential to ensure the robustness of livestock grazing in pastures, for which soil fertility is a prerequisite. Weather is a key factor affecting the quality of pastures (Baumont et al., 2014).

However, with the advent of global warming, the great adaptive plasticity of tropical grasses makes them suitable for sustainable intensification in new regions. Thus, the present study aimed to assess samples that were derived from Xaraes palisade grass, hand-plucked, and managed within the concepts of soil-plant-animal interaction. In this context, we aimed to gather the $\mathrm{N}$ fertilization rate and real-time weather and animal grazing data, which would lead to an increase of the nutritional value and digestibility of Xaraes palisade grass and enable the indirect optimization of consumption, performance and animal productivity.

\section{Materials and methods}

\subsection{Location, treatments and sampling}

The experiment was carried out at the State farm at Americana, São Paulo, Brazil, at coordinates $47^{\circ} 16^{\prime} 80^{\prime \prime}$ west longitude and $22^{\circ} 45^{\prime} 09^{\prime \prime}$ south latitude and an altitude $545 \mathrm{~m}$. The climate according to the Köppen classification is Cwa, hot and humid tropical, with the rainy season in summer and the dry season in winter. Climatological data were obtained from the Integrated Centre for Agro-meteorological Information (CIIAGRO) (Fig. 1). The monthly water balance was calculated according to the method of Rolim et al. (1998) considering a soil water storage capacity (WSC) of $175 \mathrm{~mm}$, as estimated according to the soil classification using values that were tabulated by Thornthwaite and Mather (1957).

The soil in the experimental area was classified as Melanic Gleissoil with a sandy loam texture. The composition was $669 \mathrm{~g} / \mathrm{kg}$ sand, $188 \mathrm{~g} / \mathrm{kg}$ silt, and $143 \mathrm{~g} / \mathrm{kg}$ clay, with $350 \mathrm{~g} / \mathrm{kg}$ base saturation and $13 \mathrm{mg} / \mathrm{dm}^{3}$ phosphorus.

A total of 24 plots measuring $112 \mathrm{~m}^{2}$ each $(14 \mathrm{~m} \times 8 \mathrm{~m})$, cultivated with Xaraes palisade grass, U. brizantha cv. Xaraes (Hochst. ex A. Rich.) R. D. Webster cv. Xaraes (Syn. Brachiaria brizantha cv. Xaraes) were evaluated by repeated measures (grazing cycles-CGs) with one treatment factor ( $\mathrm{N}$ rate) in a completely randomized block design, with four replications. Each block received one of the following $\mathrm{N}$ fertilization treatments: $0,125,250,375,500$ or $625 \mathrm{~kg} \mathrm{~N} / \mathrm{ha} / \mathrm{year}$ as urea (six plots per blocks) and six grazing cycles (September 22, 2009; October 20, 2009; November 17, 2009; December 16, 2009; January 13, 2010; and February 13, 2010).

After decreasing the plant height through grazing in August 2010, a total of $1.7 \mathrm{t} / \mathrm{ha}$ lime (PRNT 75\%), with a Mg content between 12 and $15 \%$, was applied to the pasture to increase the base saturation to $60 \%$. Along with the first fertilizer application, $40 \mathrm{~kg} / \mathrm{ha} \mathrm{P}_{2} \mathrm{O}_{5}$ in the form of superphosphate, corresponding to $26 \mathrm{~kg} / \mathrm{ha}$ of sulphur, was applied by broadcasting to fix the phosphorus and the sulphur. Potassium fertilization was based on the extraction of nutrients from $20 \mathrm{t} / \mathrm{ha} / \mathrm{year}$ of herbage mass (Valle et al., 2001) and $20 \mathrm{~kg} \mathrm{~K}$ in newly expanded leaf blades (Silveira et al., 2005). These values were chosen to result in a $400 \mathrm{~kg} / \mathrm{ha} / \mathrm{year}$ potassium extraction from the aerial portion of the plant, which was restored to the soil in the form of potassium chloride and was redistributed in September and November 2009 because the soil texture was sandy loam.

Soon after the removal of the grazing cows, $\mathrm{N}$ fertilization, which was distributed throughout the year, occurred in five equal applications that were alternated with grazing during the rainy season (September 22, 2009; October 19, 2009; November 16, 2009; December 14, 2009; and January 11, 2010) and always occurred after the removal of grazing animals. 


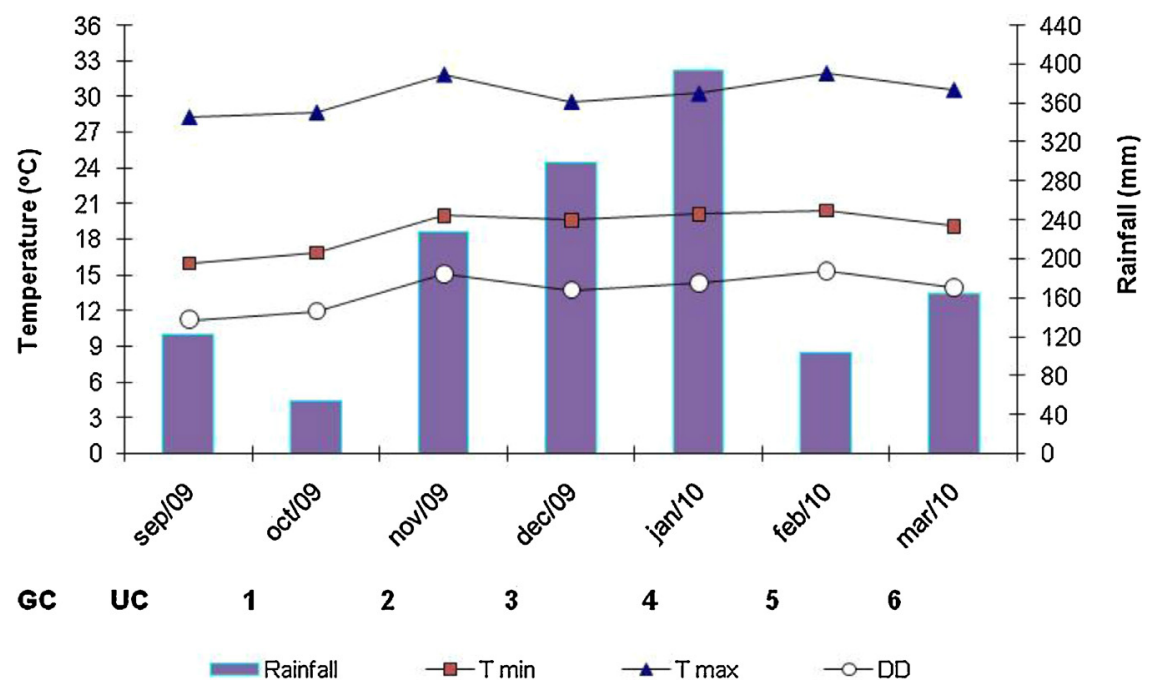

Fig. 1. Climatic data for the experimental period from 2009 to 2010 . GCs, grazing cycles; UC, grazing followed by uniform grass cutting; Tmin, minimum temperature; $T_{\max }$, maximum temperature; DD, degree days and rainfall. Initial dates of grazing cycles: GC1, October 19, 2009; GC2, November 16, 2009; GC3, December 14, 2009; GC4, January 11, 2010; GC5, February 8, 2010; GC6, March 8, 2010.

The plots were managed with rotational stocking (26 days of rest and 2 days of occupation). The post grazing height target in the first and second grazing cycles was $15-20 \mathrm{~cm}$, with only one day of occupation. In this management, an excessive loss of plants caused by lodging and trampling occurred in areas with lower rates of $\mathrm{N}$. In areas with higher rates of $\mathrm{N}$, the reduction of the stubble was difficult because the stems were thickened. As a result, two days of occupation and a new target stubble height of 24 to $27 \mathrm{~cm}$ was adopted for the other grazing cycles to ensure the continuity of the grass.

To achieve the established post-grazing height targets, dry Holstein cows were used with a body weight (BW) of $527 \mathrm{~kg}$ (SD $36 \mathrm{~kg}$ ), considering the consumption of $2.5 \%$ of BW and a $40 \%$ estimated mass loss of pre-grazing forage. Grass samples were collected after six grazing cycles and at 26 days of regrowth during summer.

We employed the grazing simulation method (hand plucking of samples) that was proposed by Sollenberger and Cherney (1995). The sampler was always the same person and was trained to minimize sampling errors. The collections were based on the routine monitoring of animal grazing habits so that the samples represented, as closely as possible, the forage mass per bite. We focused on the time of collection and changes in the animals' grazing location. There were four days of grazing simulation, which were carried out one block at a time (six plots). Samples were collected from approximately 20 points of each plot in a zigzag pattern until reaching $500 \mathrm{~g}$ of green mass before animal occupation. The samples were immediately placed in plastic bags and transported to the laboratory for drying and grinding.

The data in Table 1 were obtained from agronomic management studies of $\mathrm{N}$ fertilization with dry cows, and grazing was evaluated by Santos (2010) simultaneous to this trial. Here, these data are used exclusively for the initial characterization of the pasture.

\subsection{Sample analysis}

After collection, the samples were manually chopped, dried in a forced-air oven at $55^{\circ} \mathrm{C}$ for $72 \mathrm{~h}$ and ground using a Wiley mill with a $1-\mathrm{mm}$ sieve. Two sub-samples per treatment were analysed for dry matter (DM) at $105^{\circ} \mathrm{C}(\mathrm{DM}$; index no. 934.01), ash (index no. 942.05) ether extract (index no. 920.39; AOAC, 1990), and crude protein (CP; Wiles et al., 1998). Neutral detergent fibre (NDF; without sodium sulphite and alpha amylase, expressed inclusive of the residual ash) and acid detergent fibre (ADF; expressed inclusive of the residual ash) were analysed sequentially according to Van Soest et al. (1991) and lignin (SA) according to Robertson and Van Soest (1981), and using a filter bag technique (ANKOM Technology, 2014).

The non-fibre carbohydrate content was calculated as NFC $=1000-$ CP - NDF - ether extract - ash (Sniffen et al., 1992). Hemicellulose (HEM) was estimated as NDF minus ADF and cellulose (CEL) as ADF minus lignin (sa). The in vitro digestibility of DM (IVDMD), OM (IVOMD) and NDF (NDFD) was measured according to Goering and Van Soest (1970) adapted, by inclusion fiber bag ANKOM. Briefly, 100-mL tubes containing fiber bag with $500 \mathrm{mg}$ of sample material (dry and $1 \mathrm{~mm}$ milled), $10 \mathrm{~mL}$ of buffer solution, and $12 \mathrm{~mL}$ of rumen fluid (from a non-lactating cow that had been fed hay) were sealed and incubated (two replicates per sample) for $48 \mathrm{~h}$ at $39^{\circ} \mathrm{C}$.

The estimated in vitro digestibility of DM and NDF was obtained at the end of fermentation, after reflux of the residues for $1 \mathrm{~h}$ with neutral detergent and washing with hot water and acetone, followed by drying at $100{ }^{\circ} \mathrm{C}$. The final residue was composed of undigested cell-wall constituents (indigestible NDF). Through the initial DM and NDF contents of the samples incubated grass samples and the undigested cell-wall constituents, the IVDMD and NDFD were predicted, respectively. 
Table 1

Average plant heights and percentages of leaf blades (L), stems and sheaths (SS) in pre-grazed Xaraes palisade grass fertilized with nitrogen (N) according to grazing cycles.

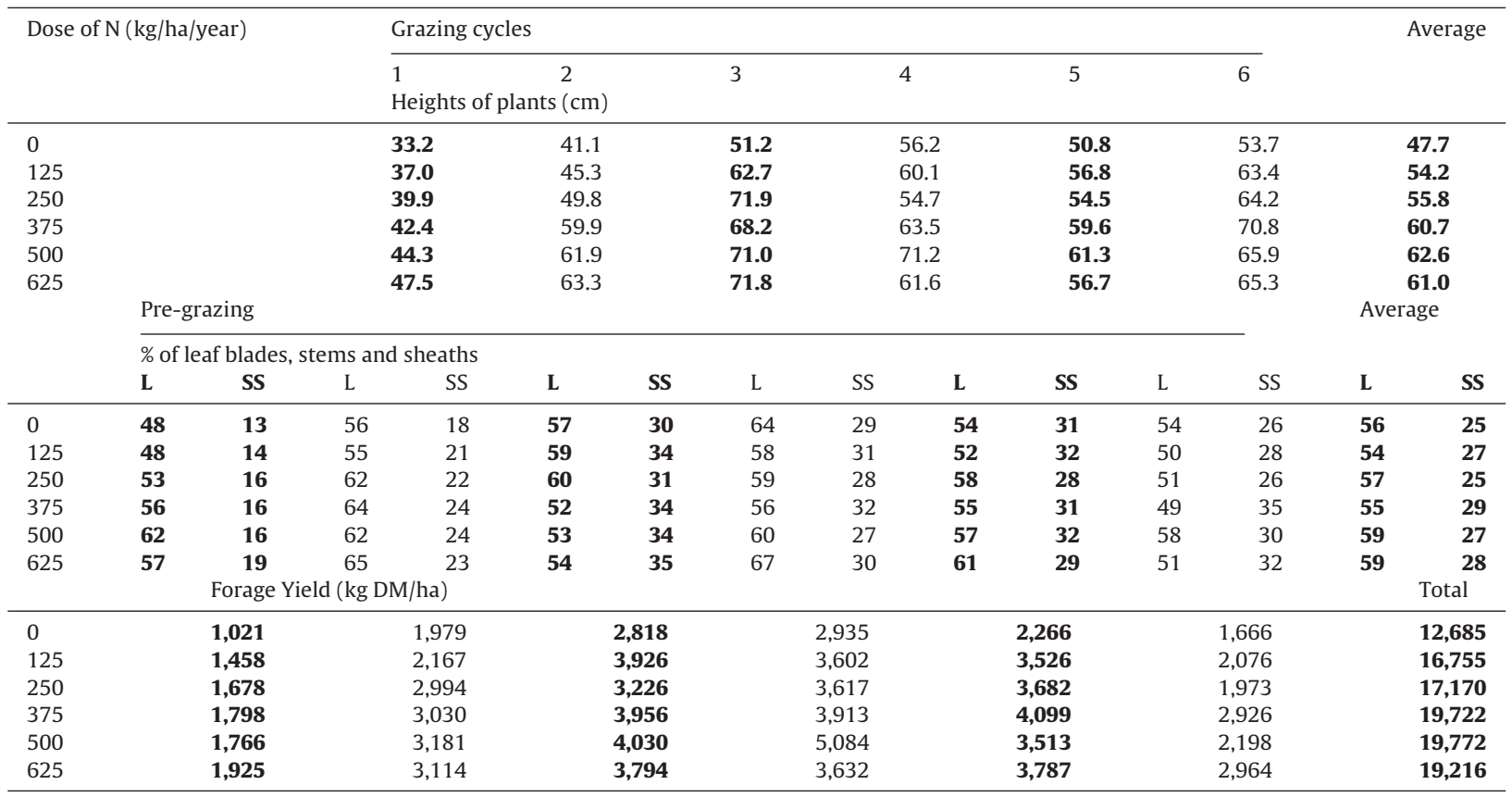

Source: adapted of Santos (2010).

The variables in bold values correspond to the unpaired grazing cycles. The other match in pairs grazing cycles.

\subsection{Calculation of the accumulated growing degree days (GDD)}

The number of growing degree days that accumulated in each grazing cycle was estimated using a base temperature for Xaraes palisade grass of $10.9^{\circ} \mathrm{C}$ according to Lara (2011). The GDD calculation was obtained by the following equation:

$$
\mathrm{GDD}=\sum[(T \mathrm{~m}-T \mathrm{~b})-C](\text { used when the average of the minimum temperature was higher than } T \mathrm{~b})
$$

where GDD is the accumulated degree days in each grazing cycle; Tm is average of the minimum and maximum temperatures; $\mathrm{Tb}$ is the base temperature; and $C$ is the correction coefficient for a $\mathrm{Tm}$ higher than $40^{\circ} \mathrm{C}$. We did not use the $C$ coefficient because the average temperature in the grazing cycles was higher than the base temperature.

\subsection{Statistical analysis}

The experiment was carried with repeated measures (grazing cycles-GCs) and one treatment factor ( $\mathrm{N}$ rate) in completely randomized block design, with four replications. The data were analysed using the MIXED procedure of SAS Institute (2003) and the autoregressive covariance structure was chosen based on the Akaike information criterion (AIC). Nitrogen rates were calculated in the plots and grazing cycles as subplots. The model that was used was as follows:

$$
Y_{i j k}=\mu+B_{i}+C_{j}+D_{k}+\mathrm{CD}_{j k}+\varepsilon_{i j k}
$$

where $Y_{\mathrm{ijk}}=$ observation, $\mu=$ population mean, $B_{i}=$ block effect $(i=1-4), C_{j}=\mathrm{N}$ rate effect $(j=1-6), D_{k}=$ grazing cycle effect $(k=1-6), \mathrm{CD}_{j k}=$ effect of grazing cycle $\times \mathrm{N}$ rate interaction, and $\varepsilon_{i j k}=$ residual error. Significant differences were accepted if $P \leq 0.05$. For significant interactions, orthogonal polynomial contrasts, using MIXED procedure of SAS Institute (2003), were performed to compare the $\mathrm{N}$ rate effects in each grazing cycle, whereas Tukey's test was used to compare the means of the effect of the grazing cycles for each nitrogen rate.

To evaluate the effect of the GDD variable on the forage yield (FY) and the digestibility of DM, OM and NDF of the Xaraes palisade grass samples for each $\mathrm{N}$ rate we used polynomial regression analysis, using REG procedure of SAS Institute (2003). Significant differences were accepted if $P \leq 0.05$. 


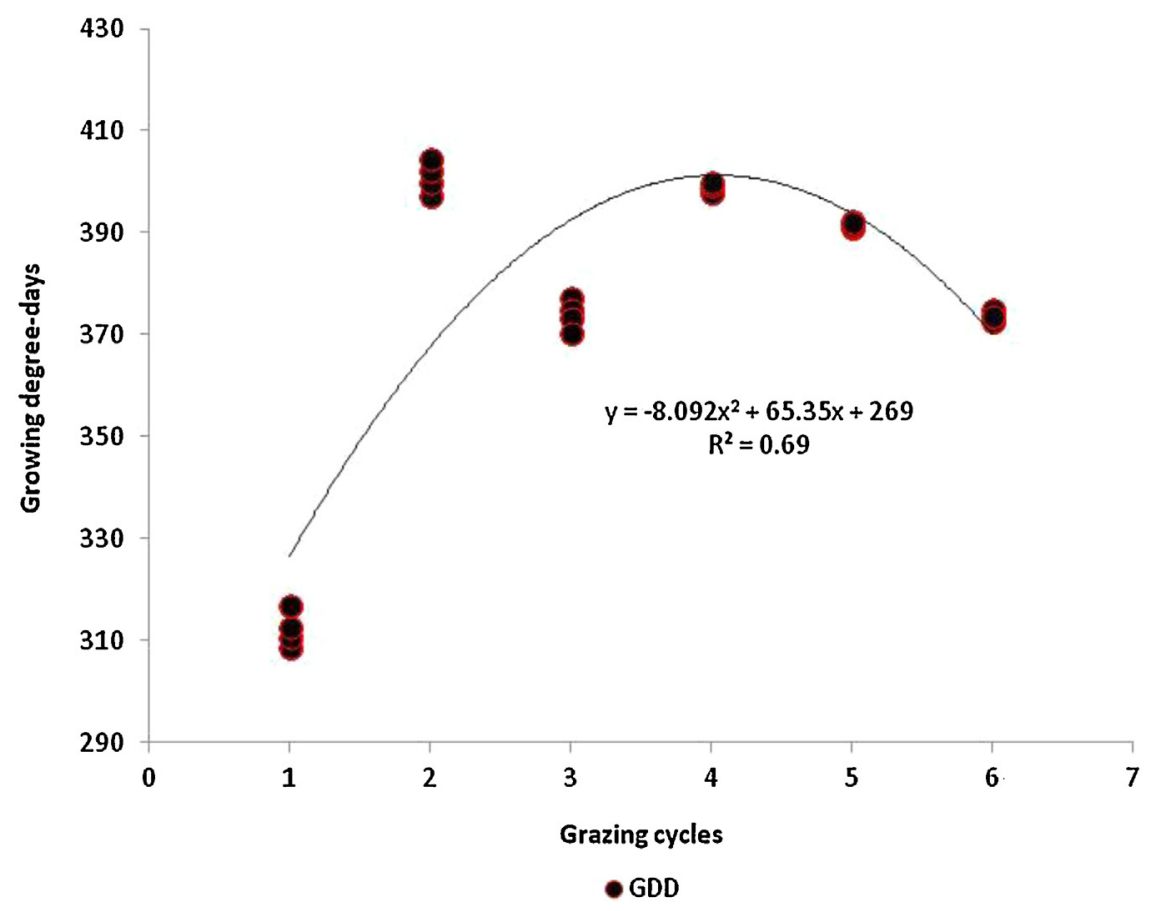

Fig. 2. Relationships between grazing cycles (GCs) and growing degree days (GDD). Initial GC dates and average GDD: GC1, October 19, 2009, 312; GC2, November 16, 2009, 401; GC3, December 14, 2009, 374; GC4, January 11, 2010, 399; GC5, February 8, 2010, 392; GC6, March 8, $2010,374$.

\section{Results}

A greater accumulation of forages occurred in GCs 3-5 (Table 1) when conferring with the highest availability of rainfall, temperatures and GDD (Figs. 1 and 2). The major soil water potential occurred in GCs 2-4, and 6 (30.1, 169.3, 243.8 and $11.9 \mathrm{~mm}$, respectively), while GCs 1 and 5 had water deficits of -11.5 and $-2.7 \mathrm{~mm}$, respectively.

The chemical composition and digestibility of the hand-plucked Xaraes palisade grass samples are shown in Tables 2-6. All of the nutrients were affected by the $\mathrm{N}$ fertilization and grazing cycles $(P<0.05)$. There was an effect of the interaction between the $\mathrm{N}$ rates and grazing cycles for almost all of the variables $(P<0.05)$. The exception was for the dry matter content (as fed), which only had a significant effect on the principal factors (Table 2). The samples that were obtained in GC4 and 5 had higher concentrations of DM compared to the other GCs $(P<0.05)$.

The mean levels of organic matter $(\mathrm{OM})$ were affected by the grazing cycle $(P<0.05)$. The OM increased linearly in GC1 and declined in GC6 $(P<0.05)$ with increasing nitrogen rates (Table 2). Quadratic effects were obtained in GC2 and 5 for OM. In the evaluation of grazing cycles with each $\mathrm{N}$ rate, the highest OM concentrations were observed in GC 4-6.

With respect to the $\mathrm{CP}$ variable (Table 2 ), there were differences in the grazing cycles for each $\mathrm{N}$ rate $(P<0.05)$. The $\mathrm{CP}$ increased linearly $(P<0.05)$ with the $N$ rate in each grazing cycle. Each kilogram of $N$ resulted in a percentage point increase in CP content. There was a decreasing trend in the N utilization rate for the CP variable, from $0.073,0.094,0.0750 .065,0.048$ and 0.041 , depending on the applied $\mathrm{N}$ dose $(0-625 \mathrm{~kg} \mathrm{~N} / \mathrm{ha} / \mathrm{year})$.

The average levels of EE were affected by the grazing cycle within each $\mathrm{N}$ rate $(P<0.05)$. A linear increase was observed for EE in GC1, 3 and 4 and a quadratic effect in GC2 and 3.

In the grazing cycles, there were differences in the NFC levels for the evaluated N rates (Table 3). The NFC variable showed decreasing linear responses (GC1 and 2) and a linear increase (GC5) with increasing N fertilization.

The average levels of NDF, CEL, HEM and lignin were affected $(P<0.05)$ by the grazing cycle within each $\mathrm{N}$ rate $($ Table 4$)$. The NDF decreased linearly with the $N$ rate according to the grazing cycle (2-6), and there were percentage point decreases $(-0.06,-0.09,-0.05,-0.06$, and -0.04$)$ in the NDF content across these cycles with each kilogram of N applied (Table 3$)$. Nitrogen fertilization led to a linear and quadratic effect for CEL, HEM and lignin-dependent GC. There was a linear increase in lignin for GC1, 3, 5 and 6 and a quadratic effect for GC5 (Table 4).

For each $\mathrm{N}$ rate and grazing cycle, significant differences were observed among the evaluated digestibility values (Table 5). IVDMD, IVOMD and NDFD responded linearly and quadratically with increasing $\mathrm{N}$ fertilization rates in almost all of the grazing cycles $(P<0.05)$.

IVDMD increased linearly with $\mathrm{N}$ fertilization in GC1 and 3-5, while GC6 decreased linearly (Table 5). In turn, in GC1 and GC3 to 6 , the responses were quadratic. The minimum responses by the regression equation were 220 and $228 \mathrm{~kg} \mathrm{~N} / \mathrm{ha}$ for GC1 and 3, respectively, and the maximum responses were 548, 386, and $192 \mathrm{~kg} \mathrm{~N} /$ ha for GC4, 5 and 6, respectively. The IVOMD 
Table 2

Influence of nitrogen fertilization and the grazing cycle (GC) on the content of dry matter (DM, as feed), organic matter (OM) and crude protein (CP) of Xaraes palisade grass harvested by hand plucking.

\begin{tabular}{|c|c|c|c|c|c|c|c|c|c|c|}
\hline \multirow[b]{2}{*}{ Cycles } & \multicolumn{7}{|c|}{ Nitrogen application rate (kg/ha/year) } & \multirow[t]{2}{*}{ SEM } & \multicolumn{2}{|l|}{$P$-value ${ }^{a}$} \\
\hline & 0 & 125 & 250 & 375 & 500 & 625 & Average & & $\mathrm{L}$ & Q \\
\hline & \multicolumn{10}{|c|}{ DM, (g/kgas fed $\left.{ }^{\mathrm{b}}\right)$} \\
\hline GC1 & 199 & 193 & 183 & 182 & 168 & 168 & $182 \mathrm{c}$ & 2.52 & - & - \\
\hline GC 2 & 220 & 232 & 185 & 191 & 175 & 187 & $193 \mathrm{~b}$ & 2.52 & - & - \\
\hline GC 3 & 220 & 148 & 192 & 193 & 187 & 184 & $196 \mathrm{~b}$ & 2.52 & - & - \\
\hline GC 4 & 220 & 209 & 192 & 196 & 188 & 185 & $198 \mathrm{ab}$ & 2.52 & - & - \\
\hline GC 5 & 219 & 209 & 202 & 200 & 193 & 205 & $205 \mathrm{a}$ & 2.52 & - & - \\
\hline GC 6 & 212 & 205 & 196 & 192 & 185 & 194 & $198 \mathrm{~b}$ & 2.52 & - & - \\
\hline \multirow[t]{2}{*}{ Average } & 215 & 202 & 192 & 192 & 183 & 187 & - & 2.52 & $<0.0001$ & 0.0006 \\
\hline & \multicolumn{10}{|c|}{$\mathrm{OM},\left(\mathrm{g} / \mathrm{kg} \mathrm{DM}{ }^{\mathrm{c}}\right)$} \\
\hline GC1 & $807 d$ & $815 d$ & $815 d$ & 812 c & $811 \mathrm{~d}$ & $817 d$ & - & 1.94 & 0.026 & 0.345 \\
\hline GC 2 & $824 \mathrm{c}$ & $826 c$ & 834 b & 826 b & $824 \mathrm{c}$ & $822 \mathrm{~cd}$ & - & 1.94 & 0.1170 & 0.0002 \\
\hline GC 3 & $825 c$ & $826 \mathrm{c}$ & $826 \mathrm{c}$ & $821 \mathrm{~b}$ & $826 \mathrm{c}$ & $826 c$ & - & 1.94 & 0.9370 & 0.536 \\
\hline GC 4 & 835 b & 831 bc & $833 \mathrm{~b}$ & $838 \mathrm{a}$ & 834 b & $836 \mathrm{~b}$ & - & 1.94 & 0.1370 & 0.666 \\
\hline GC 5 & $845 a$ & $843 a$ & $843 a$ & $840 \mathrm{a}$ & $840 \mathrm{a}$ & $850 \mathrm{a}$ & - & 1.94 & 0.5404 & 0.0008 \\
\hline GC 6 & 835 b & $835 b$ & $832 \mathrm{~b}$ & $837 \mathrm{a}$ & $823 c$ & $825 c$ & - & 1.94 & $<0.0001$ & 0.052 \\
\hline \multirow[t]{2}{*}{ Average } & 829 & 829 & 831 & 829 & 826 & 829 & - & - & - & - \\
\hline & \multicolumn{10}{|c|}{$\mathrm{CP},\left(\mathrm{g} / \mathrm{kg} \mathrm{DM}^{\mathrm{d}}\right)$} \\
\hline GC1 & $121 \mathrm{a}$ & $128 \mathrm{ab}$ & $139 \mathrm{a}$ & $146 \mathrm{a}$ & $157 \mathrm{a}$ & $166 \mathrm{a}$ & - & 2.95 & $<0.0001$ & 0.637 \\
\hline GC 2 & $107 \mathrm{bc}$ & $121 \mathrm{bc}$ & 126 bc & $138 \mathrm{a}$ & $161 \mathrm{a}$ & $163 \mathrm{a}$ & - & 2.95 & $<0.0001$ & 0.728 \\
\hline GC 3 & $113 a b$ & $126 \mathrm{~b}$ & $134 \mathrm{ab}$ & $141 \mathrm{a}$ & $156 a b$ & $159 \mathrm{a}$ & - & 2.95 & $<0.0001$ & 0.545 \\
\hline GC 4 & $96 \mathrm{~d}$ & $108 \mathrm{~d}$ & $118 \mathrm{c}$ & $127 \mathrm{~b}$ & $137 \mathrm{c}$ & $134 \mathrm{c}$ & - & 2.95 & $<0.0001$ & 0.004 \\
\hline GC 5 & $105 \mathrm{c}$ & $113 \mathrm{~cd}$ & $124 \mathrm{c}$ & $127 \mathrm{~b}$ & $138 \mathrm{c}$ & $131 \mathrm{c}$ & - & 2.95 & $<0.0001$ & 0.007 \\
\hline GC 6 & $121 \mathrm{a}$ & $136 a$ & $141 \mathrm{a}$ & $143 \mathrm{a}$ & $148 \mathrm{~b}$ & $150 \mathrm{~b}$ & - & 2.95 & $<0.0001$ & 0.021 \\
\hline Average & 111 & 122 & 130 & 137 & 150 & 151 & - & - & - & - \\
\hline
\end{tabular}

Means within columns by variable followed by distinct letters differ significantly by Tukey's test $(P<0.05)$.

a L: linear effect for nitrogen dose; Q: quadratic effect for nitrogen dose.

b $P=0.967$ for cycle $\times$ dose interaction, $P<0.0001$ for cycle and dose effect.

c $P=0.0009$ for cycle $\times$ dose interaction.

d $P<0.0001$ for cycle $\times$ dose interaction.

showed linear (GC1 to 6) and quadratic responses (GC1, 2, and 4-6) with $\mathrm{N}$ fertilization (Table 5). The minimum response by the regression equation was $179 \mathrm{~kg} \mathrm{~N} /$ ha for GC1, and the maximum responses were 399, 541, 370, and 188 kg N/ha for GC2, 4, 5 and 6, respectively. The NDFD showed linear (GC1 to 4 and 6) and quadratic responses (GC1 and 3-5) with N fertilization (Table 5). The quadratic responses had minimum responses of 237 and $424 \mathrm{~kg} \mathrm{~N} / \mathrm{ha}$ for GC1 and 3 and maximum responses of 511 and $279 \mathrm{~kg} \mathrm{~N} /$ ha for GC4 and 5, respectively.

The significant results demonstrate the relationship between FY, NDF, IVDMD, NDFD and GDD for almost all of the N rates (Table 6). The exception was for IVDMD at a rate $250 \mathrm{~kg} \mathrm{~N} / \mathrm{ha}$, which did not fit the model of GDD $(P>0.05)$. The results adjusted the NDFD for the model involving the GDD $(P<0.05)$ from the rate $250 \mathrm{~kg} \mathrm{~N} / \mathrm{ha}$.

The maximum GDD effect was obtained in GC 4 (Fig. 2) with a quadratic response.

\section{Discussion}

Most of the nutrients of Xaraes palisade grass were affected linearly and quadratically by $\mathrm{N}$ fertilization and by grazing cycles (Tables 2-6). These results likely reflect the direct effect of pasture management, grazing animals and climatic variations in each grazing cycle. There was a change in the grass growth structure (height and leaf:stem) with grazing animal (e.g., deposition of faeces and urine, trampling, and loss of forage) combined with climatic factors that were present in each grazing cycle, such as rainfall, soil water potential, temperature, thermal variation (DD) and GDD. Nitrogen fertilization alone promoted the acceleration of grass growth when there were favourable conditions.

\subsection{Effect of grazing cycle}

The dry matter of forage is a direct response to the momentary physiological state in relation to the environmental conditions. In general, the DM and OM contents tended to increase $(P<0.05)$ in each grazing cycle (GC1 the GC6) with each dose of $\mathrm{N}$, but there was no interaction effect for the MS variable (Table 2).

In this context, we observe that in GC1 (Table 2), the grass had the lowest DM content compared to the other GC, providing the lowest accumulation of forage $\mathrm{N}$ within each dose (Table 1), lowest volume of rain (54 mm) with soil water deficits (-11.5 mm), and maximum temperature of $29.1^{\circ} \mathrm{C}$ and GDD 312 (Figs. 1 and 2). These effects led to lower DM, MO, NDF and CEL contents and a higher CP content in GCs within each dose and provided better results of IVDMD (0.79), IVOMD (0.81) and NDFD (0.43) in GC1 (Table 5). A possible explanation is related to the higher moisture retention of the soil's 
Table 3

Influence of nitrogen fertilization and the grazing cycle (GC) on the content of ether extract (EE), non-fibre carbohydrates (NFC) and neutral detergent fibre (NDF) of the Xaraes palisade grass harvested by hand plucking.

\begin{tabular}{|c|c|c|c|c|c|c|c|c|c|}
\hline \multirow[t]{2}{*}{ Cycles } & \multicolumn{7}{|c|}{ Nitrogen application rate (kg/ha/year) } & \multicolumn{2}{|l|}{$P$-value } \\
\hline & $\overline{0}$ & 125 & 250 & 375 & 500 & 625 & SEM & $\mathrm{L}$ & $\mathrm{Q}$ \\
\hline & \multicolumn{9}{|c|}{$\mathrm{EE},\left(\mathrm{g} / \mathrm{kg} \mathrm{DM}^{\mathrm{b}}\right)$} \\
\hline GC1 & $20 a^{10}$ & $19 \mathrm{~b}$ & $22 \mathrm{a}$ & $21 \mathrm{a}$ & $20 \mathrm{a}$ & $24 \mathrm{a}$ & 0.89 & 0.0134 & 0.300 \\
\hline $\mathrm{GC2}$ & $20 \mathrm{a}$ & $22 \mathrm{a}$ & $18 \mathrm{~b}$ & $19 \mathrm{a}$ & $20 \mathrm{a}$ & $22 \mathrm{a}$ & 0.89 & 0.4730 & 0.032 \\
\hline $\mathrm{GC3}$ & $15 \mathrm{~b}$ & $12 \mathrm{e}$ & $13 \mathrm{~d}$ & $16 \mathrm{~b}$ & $15 \mathrm{~b}$ & $17 \mathrm{~b}$ & 0.89 & 0.0066 & 0.070 \\
\hline GC4 & $13 \mathrm{c}$ & 13 de & $15 \mathrm{~cd}$ & $13 \mathrm{c}$ & $17 \mathrm{~b}$ & $16 \mathrm{bc}$ & 0.89 & 0.0012 & 0.953 \\
\hline GC5 & $16 \mathrm{~b}$ & $17 \mathrm{bc}$ & $16 \mathrm{bc}$ & $17 \mathrm{~b}$ & $16 \mathrm{~b}$ & $16 \mathrm{bc}$ & 0.89 & 0.7990 & 0.442 \\
\hline GC6 & $14 \mathrm{bc}$ & $16 \mathrm{~cd}$ & $14 \mathrm{~cd}$ & $15 \mathrm{bc}$ & $16 \mathrm{~b}$ & $14 \mathrm{c}$ & 0.89 & 0.8901 & 0.563 \\
\hline \multirow[t]{2}{*}{ Average } & 16 & 17 & 16 & 17 & 17 & 18 & - & - & - \\
\hline & \multicolumn{9}{|c|}{$\mathrm{NFC},\left(\mathrm{g} / \mathrm{kg} \mathrm{DM}^{\mathrm{c}}\right)$} \\
\hline GC1 & $121 \mathrm{a}$ & $124 \mathrm{a}$ & $109 a$ & $109 \mathrm{ab}$ & $97 \mathrm{ab}$ & $88 \mathrm{~b}$ & 5.16 & $<0.0001$ & 0.309 \\
\hline GC 2 & $97 \mathrm{~b}$ & $92 \mathrm{c}$ & $97 \mathrm{ab}$ & $93 \mathrm{~cd}$ & $88 \mathrm{~b}$ & $76 \mathrm{~b}$ & 5.16 & 0.0050 & 0.109 \\
\hline GC 3 & $81 \mathrm{c}$ & $76 \mathrm{~d}$ & $83 \mathrm{~b}$ & $93 \mathrm{~cd}$ & $87 \mathrm{~b}$ & $81 \mathrm{~b}$ & 5.16 & 0.3510 & 0.829 \\
\hline GC 4 & $120 \mathrm{a}$ & $107 \mathrm{~b}$ & $110 \mathrm{a}$ & $114 \mathrm{a}$ & $111 \mathrm{a}$ & $106 a$ & 5.16 & 0.1970 & 0.869 \\
\hline GC 5 & $83 \mathrm{bc}$ & $102 \mathrm{bc}$ & $94 \mathrm{~b}$ & $79 \mathrm{~d}$ & $95 \mathrm{~b}$ & $111 \mathrm{a}$ & 5.16 & 0.0200 & 0.088 \\
\hline GC 6 & $88 \mathrm{c}$ & $89 \mathrm{~cd}$ & $88 \mathrm{~b}$ & $95 \mathrm{bc}$ & $93 \mathrm{~b}$ & $80 \mathrm{~b}$ & 5.16 & 0.6630 & 0.116 \\
\hline \multirow[t]{2}{*}{ Average } & 98 & 98 & 97 & 97 & 95 & 90 & - & - & - \\
\hline & \multicolumn{9}{|c|}{$\mathrm{NDF},\left(\mathrm{g} / \mathrm{kg} \mathrm{DM}{ }^{\mathrm{d}}\right)$} \\
\hline GC1 & $647 c$ & $643 \mathrm{~d}$ & $645 c$ & $640 \mathrm{c}$ & $641 \mathrm{~b}$ & $640 \mathrm{c}$ & 4.87 & 0.2330 & 0.796 \\
\hline GC 2 & $691 \mathrm{~b}$ & $686 \mathrm{~b}$ & $687 \mathrm{a}$ & $672 \mathrm{~b}$ & 654 bc & $661 \mathrm{ab}$ & 4.87 & $<0.0001$ & 0.693 \\
\hline GC 3 & $702 \mathrm{~b}$ & $700 \mathrm{a}$ & $684 \mathrm{a}$ & $661 \mathrm{~b}$ & $656 \mathrm{~b}$ & $658 \mathrm{~b}$ & 4.87 & $<0.0001$ & 0.145 \\
\hline GC 4 & $692 \mathrm{~b}$ & $688 \mathrm{ab}$ & $677 \mathrm{ab}$ & $668 \mathrm{~b}$ & $656 \mathrm{~b}$ & $667 \mathrm{ab}$ & 4.87 & $<0.0001$ & 0.103 \\
\hline GC 5 & $719 a$ & $688 \mathrm{ab}$ & $687 \mathrm{a}$ & $703 \mathrm{a}$ & $677 a$ & $672 \mathrm{a}$ & 4.87 & $<0.0001$ & 0.539 \\
\hline GC 6 & $690 \mathrm{~b}$ & $672 \mathrm{c}$ & $670 \mathrm{~b}$ & $660 \mathrm{~b}$ & 653 bc & $667 \mathrm{ab}$ & 4.87 & $<0.0001$ & 0.0012 \\
\hline Average & 690 & 680 & 675 & 667 & 656 & 661 & - & - & - \\
\hline
\end{tabular}

Means within columns by variable followed by distinct letters differ significantly by Tukey's test $(P<0.05)$.

a $\mathrm{L}$ : linear effect for nitrogen dose; $\mathrm{Q}$ : quadratic effect for nitrogen dose.

b $P=0.0009$ for cycle $\times$ dose interaction.

c $P<0.0001$ for cycle $\times$ dose interaction effect.

d $P<0.0001$ for cycle $\times$ dose interaction effect.

remaining material after initial mechanical cutting for the standardization of pasture (cut near the soil surface). According to Dahiya et al. (2007), mulching plays a basic role in reducing soil water loss. Silva et al. (2012) reported that soil moisture maintains the cell turgor pressure of plants, regulates the functioning of stomatal and increases the availability of $\mathrm{N}$ and solar radiation, causing a higher photosynthetic efficiency, which activates the enzymes rubisco and PEP carboxylase to increase $\mathrm{PB}$ on the leaves.

However, the CP results varied within GC by rates not similar to other nutrients. Silva et al. (2012) also reported mixed results regarding the crude protein $(98-178 \mathrm{~g} / \mathrm{kg})$ and $\mathrm{NDF}(623-736 \mathrm{~g} / \mathrm{kg})$ of Xaraes palisade grass when evaluated for 10 months under irrigation conditions.

There were changes in GC4 and 5 compared to GC1, where grasses had the highest DM (198 and $205 \mathrm{~g} / \mathrm{kg}$ ) and forage accumulation (Tables 1 and 2), generating greater volumes of rainfall ( 394 and $104 \mathrm{~mm}$ ) and an increased soil water potential (244 $\mathrm{mm}$ and deficit $-2.7 \mathrm{~mm}$ ), with maximum temperatures (29.6 and $32.4{ }^{\circ} \mathrm{C}$ ) and peak GDDs (399 and 392 ), respectively. These facts had repercussions in the larger DM and OM of the grass.

However, when there was heavier rainfall in GC4 and lower rainfall in GC5 (Fig. 1); the CP content was lower at each N rate (Table 2) compared to that of other groups $(P<0.05)$. This difference likely affected the process of soil $\mathrm{N}$ dilution or leaching caused by rainfall (Fig. 1). The excess water in the soil (soaking) likely promoted the plants' defence mechanisms to diminish the uptake of water and nutrients contained in the soil type (Melanic Gleissoil with sandy loam texture). In physiological terms, Larch $(2004,1994)$ mentioned that when a plant cell is fully saturated with water, there is an interruption of the root nutrient absorption process as a defence mechanism under conditions of excess water in the soil and on the surface. Pequeno et al. (2015) also found a reduction in the crude protein content and increased NDF concentration of grasses, Mulato II (Convert HD 364) and Marandu, evaluated during the rainy season under irrigation conditions. In GC5, there was also decreased CP, but there was an increase in the NDF content compared to the other GCs. In this cycle, there was less rainfall and fewer soil water deficits.

In general, there was an increase $(P<0.05)$ in the NDF, CEL, HEM and lignin contents and a reduction in the EE and NFC contents $(P<0.05)$ between the GCs according to the N levels (Tables $2-4)$, as clearly demonstrated in GC3, where there were high CEL and lignin contents and low HEM and NFC contents at each N rate (Table 4). This reduction in NFC and HEM likely resulted in grass growth (forage accumulation-Table 1). According to Trenholm et al. (1998), with grasses under intense growth, the NFC reserves are mostly used for fibre synthesis. The faster growth of the grass can be observed by the effects of $\mathrm{N}$ fertilization (Table 1), rainfall (Fig. 1, $299 \mathrm{~mm})$, soil water potential $(169 \mathrm{~mm})$, higher temperature $\left(29.6^{\circ} \mathrm{C}\right)$, DD of 13.7 and GDD of 372 (Figs. 1 and 2) and regrowth period of grasses. These factors provide the conditions that are necessary to 
Table 4

Influence of nitrogen fertilization and the grazing cycle (GC) on the content of cellulose (CEL), hemicellulose (HEM) and lignin of the Xaraes palisade grass harvested by hand plucking.

\begin{tabular}{|c|c|c|c|c|c|c|c|c|c|}
\hline \multirow[t]{2}{*}{ Cycles } & \multicolumn{7}{|c|}{ Nitrogen application rate (kg/ha/year) } & \multicolumn{2}{|l|}{$P$-value ${ }^{a}$} \\
\hline & 0 & 125 & 250 & 375 & 500 & 625 & SEM & $\mathrm{L}$ & Q \\
\hline & \multicolumn{9}{|c|}{ CEL, (g/kg DM $\left.{ }^{\mathrm{b}}\right)$} \\
\hline GC1 & $299 \mathrm{c}$ & $303 c$ & $304 d$ & $295 \mathrm{e}$ & 304 bc & $296 \mathrm{~d}$ & 3.68 & 0.6350 & 0.405 \\
\hline GC 2 & $318 b$ & $317 \mathrm{~b}$ & 322 bc & $319 c$ & $301 \mathrm{c}$ & $303 \mathrm{~cd}$ & 3.68 & $<0.0001$ & 0.022 \\
\hline GC 3 & $342 \mathrm{a}$ & $333 \mathrm{a}$ & $334 \mathrm{a}$ & $338 \mathrm{a}$ & $332 \mathrm{a}$ & $331 \mathrm{a}$ & 3.68 & 0.0710 & 0.637 \\
\hline GC 4 & $339 a$ & 333 a & $333 \mathrm{a}$ & 325 bc & $324 \mathrm{a}$ & $335 \mathrm{a}$ & 3.68 & 0.0920 & 0.022 \\
\hline GC 5 & $338 \mathrm{a}$ & $340 \mathrm{a}$ & $325 \mathrm{ab}$ & $330 \mathrm{ab}$ & $313 \mathrm{~b}$ & 315 b & 3.68 & $<0.0001$ & 0.685 \\
\hline GC 6 & $319 b$ & $317 \mathrm{~b}$ & $315 c$ & $306 \mathrm{~d}$ & $314 \mathrm{~b}$ & 309 bc & 3.68 & 0.0350 & 0.487 \\
\hline \multirow[t]{2}{*}{ Average } & 326 & 324 & 322 & 319 & 315 & 315 & - & - & - \\
\hline & \multicolumn{9}{|c|}{ HEM, (g/kg DM $\left.{ }^{\mathrm{c}}\right)$} \\
\hline GC1 & $292 \mathrm{e}$ & $290 \mathrm{~d}$ & $292 \mathrm{~b}$ & $297 c$ & $288 \mathrm{~b}$ & $296 \mathrm{~cd}$ & 3.90 & 0.6040 & 0.786 \\
\hline GC 2 & $318 b$ & $319 a$ & $319 a$ & $309 \mathrm{~b}$ & $310 \mathrm{a}$ & 315 a & 3.90 & 0.0852 & 0.471 \\
\hline GC 3 & 300 de & $310 a b$ & 297 b & $272 \mathrm{~d}$ & $273 c$ & $275 \mathrm{e}$ & 3.90 & $<0.0001$ & 0.653 \\
\hline GC 4 & $305 \mathrm{~cd}$ & $309 a b c$ & 299 b & $293 c$ & 281 bc & $289 \mathrm{~d}$ & 3.90 & $<0.0001$ & 0.816 \\
\hline GC 5 & $333 \mathrm{a}$ & $299 \mathrm{~cd}$ & $314 \mathrm{a}$ & $325 \mathrm{a}$ & $315 \mathrm{a}$ & $311 \mathrm{ab}$ & 3.90 & 0.1470 & 0.159 \\
\hline GC 6 & 313 bc & 300 bcd & $299 \mathrm{~b}$ & 298 bc & 283 bc & 303 bc & 3.90 & 0.0031 & 0.003 \\
\hline \multirow[t]{2}{*}{ Average } & 310 & 260 & 303 & 299 & 292 & 298 & - & - & \\
\hline & \multicolumn{9}{|c|}{ Lignin, (g/kg DM $\left.{ }^{\mathrm{d}}\right)$} \\
\hline GC1 & $32 \mathrm{ab}$ & $30 \mathrm{~b}$ & $32 \mathrm{a}$ & $32 \mathrm{~b}$ & $35 \mathrm{a}$ & $34 \mathrm{bc}$ & 0.72 & $<0.0001$ & 0.316 \\
\hline GC 2 & $32 \mathrm{a}$ & 32 a & $32 \mathrm{a}$ & $32 \mathrm{bc}$ & $32 \mathrm{~b}$ & $33 c$ & 0.72 & 0.6940 & 0.252 \\
\hline GC 3 & $30 \mathrm{~b}$ & $32 \mathrm{ab}$ & $32 \mathrm{a}$ & $32 \mathrm{~b}$ & $32 \mathrm{~b}$ & $35 \mathrm{ab}$ & 0.72 & $<0.0001$ & 0.452 \\
\hline GC 4 & $30 \mathrm{~b}$ & $30 \mathrm{~b}$ & $32 \mathrm{a}$ & $30 \mathrm{c}$ & $32 \mathrm{~b}$ & $31 \mathrm{~d}$ & 0.72 & 0.3850 & 0.260 \\
\hline GC 5 & $28 \mathrm{c}$ & $31 \mathrm{ab}$ & $31 \mathrm{a}$ & 33ab & $34 \mathrm{ab}$ & $31 \mathrm{~d}$ & 0.72 & $<0.0001$ & 0.0001 \\
\hline GC 6 & $33 a$ & $31 \mathrm{ab}$ & $32 \mathrm{a}$ & $35 a$ & $35 a$ & $37 \mathrm{a}$ & 0.72 & $<0.0001$ & 0.048 \\
\hline Average & 31 & 31 & 32 & 32 & 33 & 34 & - & - & \\
\hline
\end{tabular}

Means within columns by variable followed by distinct letters differ significantly by Tukey's test $(P<0.05)$.

a $\mathrm{L}$ : linear effect for nitrogen dose; Q: quadratic effect for nitrogen dose.

b $P=0.0002$ for cycle $\times$ dose interaction.

c $P<0.0001$ for cycle $\times$ dose interaction effect.

d $P<0.0001$ for cycle $\times$ dose interaction effect.

change the vegetative development of adult plants with carbohydrates and nutrients available in the soil. Van Soest (1994) reported that the temperatures in the tropics enhanced the metabolic activities for forming structural components of plants.

In this context, Sinclair and Selligman (1995) reported that maturity is a physiological process that is accelerated by the environmental temperature, promoting changes in both the chemical composition and morphology of the grass, especially in relation to the leaf:stem ratio. This promotion is one of the main factors affecting the nutritional value of tropical forages.

According to Pedreira and Pedreira (2007), the good stewardship of Xaraes palisade grass in rotational grazing and cows should be generated with a grazing interval of less than 28 days to allow greater canopy photosynthesis values over the regrowth cycle. Pedreira et al. (2009) found that a rest period greater than 28 days in the summer increases the mass production of grass in pre-grazing, but negatively affects the nutritional value of forage and animal performance by stem accumulation and dead materials. Vendramini et al. (2014) evaluated hybrid Brachiaria harvested during a regrowth period of 42 days and reported that this time expires the period of growth, reduces the accumulation of forage, increases the senescence of the leaf and consequently reduces the digestibility MO. However, in this experiment, which was carried out with a regrowth period of 26 days, the results of the chemical composition and digestibility presented different results for the different fertilizer rates $\mathrm{N}$ in different grazing cycles of the grass with animals and a climatic interference (Tables 1-6).

Hughes et al. (2014) suggests that the extent of forage digestibility is influenced by a combination of interrelated factors rather than isolated factors. In this sense, Van Soest (1967) already mentioned that the dry matter forage is a group of factors that impact digestibility differently. However, we noticed that the lignin content of the samples that were collected by hand plucking with the highest $\mathrm{N}$ rate $(625 \mathrm{~kg} \mathrm{~N} / \mathrm{ha} / \mathrm{year})$ in GC3 and 6 was highest (Table 4,35 and $37 \mathrm{~g} / \mathrm{kg}$ DM), which had the greatest impact on the digestibility MS, MO and NDF of grass (Table 5). We know that the stalks of tropical grasses are the structures that lignify the growth and maturity of the plant to a greater extent. However, samples that were collected hand plucking were mostly made up of leaves, suffering the effects of the redistribution of assimilates and phenolic compounds produced in the growth process. In rapidly growing grasses, hemicellulose and cellulose accumulation normally occurs at a significantly higher rate than does lignin accumulation. Thus, lignin accumulation usually accelerates during periods of stress due to climatic variation, slow growth, defoliation effect and the previous grazing cycle, which affect the pasture's physical structure (post-grazing residue), among others. This fact agrees with the concept of Dryden (2008), who stated that the spatial distribution of lignin affects the digestibility more than the concentration. Variations in the results of each grazing cycle during this trial are probably linked to the mentioned environmental factors.

According to Wilson (1976), under conditions of rapid growth, the stem tracheids mature rapidly, even with thin walls, because the highly active meristematic regions drain most of the available assimilates. Thus, fewer carbohydrates are avail- 
Table 5

In vitro digestibility coefficients of dry matter (IVDMD), organic matter (IVOMD) and neutral detergent fibre (NDFD) of the Xaraes palisade grass harvested by hand plucking.

\begin{tabular}{|c|c|c|c|c|c|c|c|c|c|}
\hline \multirow[b]{2}{*}{ Cycles } & \multicolumn{7}{|c|}{ Nitrogen application rate (kg/ha/year) } & \multicolumn{2}{|l|}{$P$-value ${ }^{\mathrm{a}}$} \\
\hline & 0 & 125 & 250 & 375 & 500 & 625 & SEM & $\mathrm{L}$ & $\mathrm{Q}$ \\
\hline & IVDMD $^{\mathrm{b}}$ & & & & & & & & \\
\hline GC1 & $0.74 \mathrm{a}$ & $0.74 \mathrm{a}$ & $0.71 b c$ & $0.75 \mathrm{a}$ & $0.74 \mathrm{a}$ & $0.79 \mathrm{a}$ & 0.007 & $<0.0001$ & $<0.0001$ \\
\hline GC 2 & $0.72 \mathrm{~b}$ & $0.72 \mathrm{~b}$ & $0.72 \mathrm{ab}$ & $0.74 \mathrm{ab}$ & $0.73 a b$ & $0.73 \mathrm{bc}$ & 0.007 & 0.0750 & 0.255 \\
\hline GC 3 & $0.68 \mathrm{c}$ & $0.68 \mathrm{c}$ & $0.70 \mathrm{c}$ & $0.67 \mathrm{c}$ & $0.67 \mathrm{c}$ & $0.71 \mathrm{~cd}$ & 0.007 & 0.0220 & 0.015 \\
\hline GC 4 & 0.67 c & $0.68 \mathrm{c}$ & $0.72 a b$ & $0.73 \mathrm{ab}$ & $0.74 \mathrm{a}$ & $0.74 \mathrm{~b}$ & 0.007 & $<0.0001$ & 0.0006 \\
\hline GC 5 & $0.68 \mathrm{c}$ & $0.73 \mathrm{ab}$ & $0.73 \mathrm{a}$ & $0.73 \mathrm{ab}$ & $0.72 \mathrm{~b}$ & $0.72 \mathrm{bc}$ & 0.007 & 0.0036 & 0.0001 \\
\hline GC 6 & $0.74 \mathrm{ab}$ & $0.74 \mathrm{ab}$ & $0.74 \mathrm{a}$ & $0.72 \mathrm{~b}$ & $0.74 \mathrm{a}$ & $0.70 \mathrm{~d}$ & 0.007 & 0.0015 & 0.015 \\
\hline \multirow[t]{2}{*}{ Average } & 0.71 & 0.72 & 0.72 & 0.72 & 0.72 & 0.73 & - & - & - \\
\hline & IVOMD $^{c}$ & & & & & & & & \\
\hline GC1 & $0.75 \mathrm{ab}$ & $0.77 \mathrm{a}$ & $0.73 \mathrm{c}$ & $0.77 \mathrm{a}$ & $0.76 \mathrm{a}$ & $0.81 \mathrm{a}$ & 0.0073 & $<0.0001$ & 0.0006 \\
\hline GC 2 & 0.74 bc & $0.75 \mathrm{~b}$ & 0.74 bc & $0.77 \mathrm{a}$ & $0.76 \mathrm{a}$ & $0.75 \mathrm{~b}$ & 0.0073 & 0.0228 & 0.0095 \\
\hline GC 3 & $0.72 \mathrm{c}$ & $0.72 \mathrm{c}$ & $0.75 \mathrm{ab}$ & $0.72 \mathrm{~b}$ & $0.74 \mathrm{~b}$ & $0.77 \mathrm{~b}$ & 0.0073 & 0.0004 & 0.1915 \\
\hline GC 4 & $0.69 \mathrm{~d}$ & $0.71 \mathrm{c}$ & $0.75 a b c$ & $0.76 \mathrm{a}$ & $0.77 \mathrm{a}$ & $0.76 \mathrm{~b}$ & 0.0073 & $<0.0001$ & 0.0002 \\
\hline GC 5 & $0.72 \mathrm{c}$ & $0.77 \mathrm{a}$ & $0.77 \mathrm{a}$ & $0.77 \mathrm{a}$ & $0.76 \mathrm{a}$ & $0.76 \mathrm{~b}$ & 0.0073 & 0.0090 & $<0.0001$ \\
\hline GC 6 & $0.76 \mathrm{a}$ & $0.76 \mathrm{ab}$ & $0.77 \mathrm{a}$ & $0.74 \mathrm{~b}$ & $0.77 \mathrm{a}$ & $0.72 \mathrm{c}$ & 0.0073 & 0.0014 & 0.0194 \\
\hline \multirow[t]{2}{*}{ Average } & 0.73 & 0.75 & 0.75 & 0.76 & 0.76 & 0.76 & - & - & - \\
\hline & $\mathrm{NDFD}^{\mathrm{d}}$ & & & & & & & & \\
\hline GC1 & $0.38 \mathrm{~cd}$ & $0.39 \mathrm{~b}$ & $0.35 \mathrm{c}$ & $0.39 \mathrm{c}$ & $0.38 \mathrm{a}$ & $0.43 \mathrm{a}$ & 0.0070 & $<0.0001$ & $<0.0001$ \\
\hline GC 2 & $0.41 \mathrm{ab}$ & $0.41 \mathrm{a}$ & $0.41 \mathrm{a}$ & $0.41 \mathrm{~b}$ & $0.39 \mathrm{a}$ & $0.39 \mathrm{bc}$ & 0.0070 & 0.0083 & 0.1670 \\
\hline GC 3 & $0.38 \mathrm{~d}$ & $0.38 \mathrm{~b}$ & $0.38 \mathrm{~b}$ & $0.33 \mathrm{~d}$ & $0.33 \mathrm{~b}$ & $0.37 \mathrm{~cd}$ & 0.0070 & $<0.0001$ & 0.0005 \\
\hline GC 4 & $0.36 \mathrm{e}$ & $0.37 \mathrm{~b}$ & $0.40 \mathrm{a}$ & $0.40 \mathrm{bc}$ & $0.40 \mathrm{a}$ & $0.40 \mathrm{~b}$ & 0.0070 & $<0.0001$ & 0.0170 \\
\hline GC 5 & $0.40 \mathrm{bc}$ & $0.41 \mathrm{a}$ & $0.42 \mathrm{a}$ & $0.43 \mathrm{a}$ & $0.40 \mathrm{a}$ & $0.39 \mathrm{~b}$ & 0.0070 & 0.1761 & 0.0008 \\
\hline GC 6 & $0.43 \mathrm{a}$ & $0.41 \mathrm{a}$ & $0.41 \mathrm{a}$ & $0.38 \mathrm{c}$ & $0.40 \mathrm{a}$ & $0.37 \mathrm{~d}$ & 0.0070 & $<0.0001$ & 0.7880 \\
\hline Average & 0.39 & 0.40 & 0.40 & 0.39 & 0.38 & 0.39 & - & - & - \\
\hline
\end{tabular}

Means within columns by variable followed by distinct letters differ significantly by Tukey's test $(P<0.05)$.

a $\mathrm{L}$ : linear effect for nitrogen dose; $\mathrm{Q}$ : quadratic effect for nitrogen dose.

b $P<0.0001$ for cycle $\times$ dose interaction effect.

c $P<0.0001$ for cycle $\times$ dose interaction effect.

d $P<0.0001$ for cycle $\times$ dose interaction effect.

able for the secondary thickening and lignification of the cell walls before the tracheids mature and lose their cytoplasm. This process most likely occurred in our trial, as shown by the fibrous composition of grass (NDF, CEL, HEM and lignin) (Tables 3 and 4). Nave et al. (2010) evaluated Xaraes palisade grass leaves during six grazing periods and found increased NDF, ADF and lignin contents and leaf shear resistance.

Changes in the composition of grass nutrients resulted in changes in digestibility (Table 5) according to the grazing cycle and $\mathrm{N}$ fertilization rate. There were significant differences in each GC within each dose of $\mathrm{N}$ to the measured digestibility (Table 5). Indeed, these results differ from those presented by Nave et al. (2010), who did not report significant differences between the six grazing periods, with a 28 -days rest interval, in the digestibility of the palisade grass Xaraes.

In GC1 and 6 were moments of a lower volume of rainfall but with the best results of IVDMD and IVDMO for nearly all doses of N. DNDF did not have the same pattern as that of IVDMD and IVDMO, demonstrating that the climatic factors in each GC, fertilization and management affected grass quality, as it is a dynamic process in animal production in pastures.

\subsection{Effect of nitrogen fertilization}

The linear decrease in the DM, NDF, NFC, CEL, and HEM contents, followed by a linear increase in CP, EE and lignin depending on the $\mathrm{N}$ rates in almost all of the grazing cycles (Tables 2-4), resulted in IVDMD, IVOMD and NDFD being increased linearly with $\mathrm{N}$ fertilization (Table 5) in most of the grazing cycles. Similar results were found by Campos et al. (2013), who reported linear reductions of HEM and NFC and linear increases of CP, lignin and CEL with the increasing total $\mathrm{N}$ fertilization of Milenio grass samples-Panicum maximum (cut near the soil surface).

Nevertheless, the change in CP from the lowest to the highest content was $96-166 \mathrm{~g} / \mathrm{kg}$ in GC. There was sufficient CP (zero $\mathrm{N}$ rate, $96 \mathrm{~g} / \mathrm{kg}$ ) NDF and quality of microbial growth and digestion in the grass leaves (Table 5). However, with the increasing $\mathrm{N}$ rate, the CP content and the digestibility of DM, OM and NDF increased linearly $(P<0.05)$, with the exception of digestibility in GC6. According to Minson and Milford (1967), microbial growth and fibre digestion are affected when the $\mathrm{CP}$ content falls below 60 to $80 \mathrm{~g} / \mathrm{kg}$ and consequently decreases the DM intake.

However, in GC6, there was a linear decrease in digestibility (IVDMD, IVOMD and NDFD) with the increasing N rate. At that moment (GC6), the HEM and NFC contents (Table 4) decreased linearly, while the CP and lignin contents increased with the N rate, reflecting the moderate growth from 2198 to $2964 \mathrm{~kg}$ dry mass/ha from GC5 to GC6 (Table 1). The digestibility reduction that was observed in GC6 coincided with the moment of lowest precipitation ( $165 \mathrm{~mm}$ rainfall) and lowest water potential in the soil $(11.9 \mathrm{~mm})$, when the average temperature was $31^{\circ} \mathrm{C}$ and there was an inflection point of the GDD curve 


\section{Table 6}

Relationship of growing degree days (GDD) between forage yield (FY), NDF and digestibility of DM and NDF of Xaraes palisade grass harvested by hand plucking.

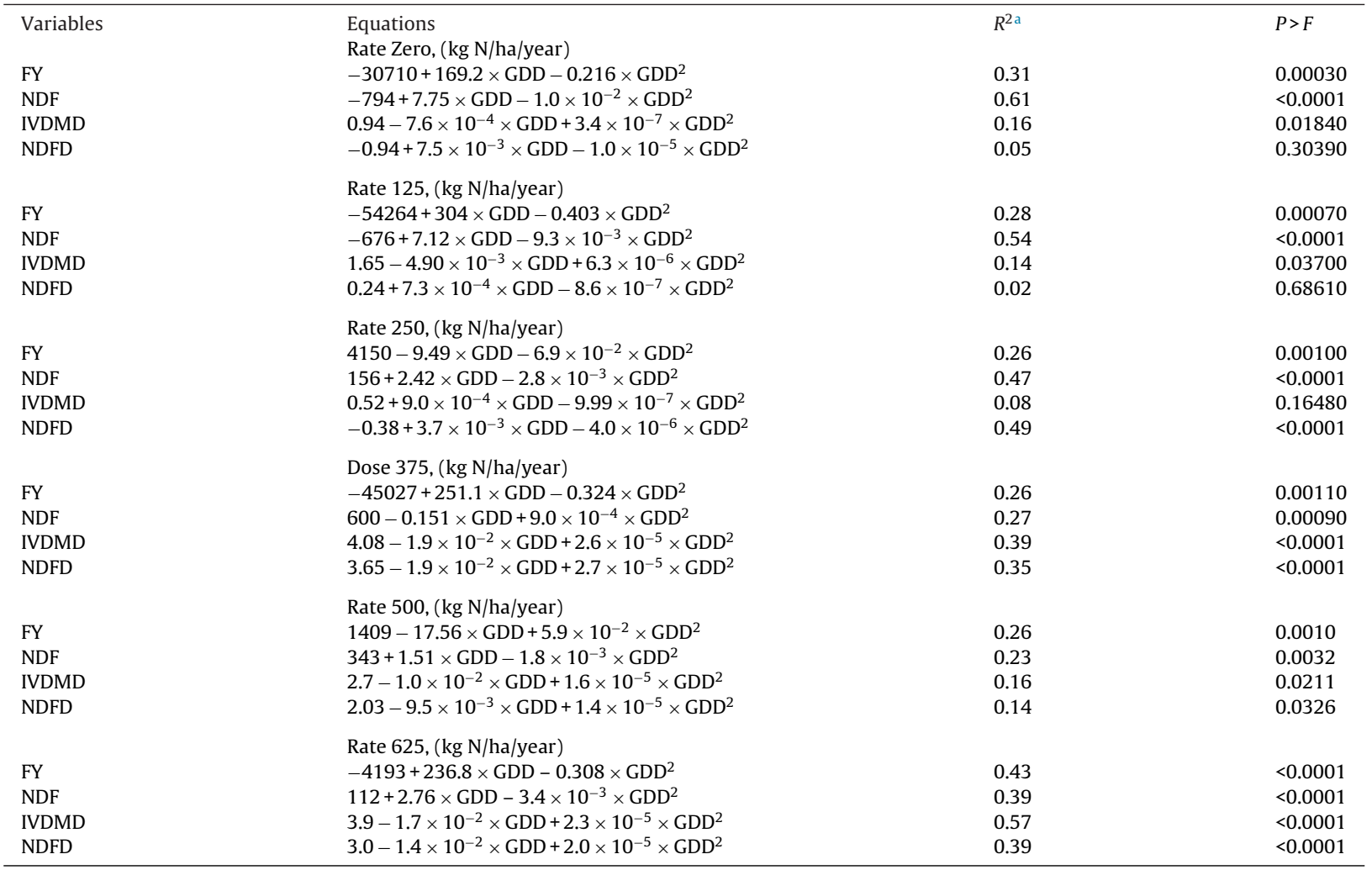

a Adjusted $R$-square and significant models if $P \leq 0.05$ by $F$-test.

(374) (Figs. 1 and 2). Other factors are probably associated with the grass height, which was approximately $65 \mathrm{~cm}$, and grass growth accumulation, but only moderately because of the low soil water deficit $(-2.7 \mathrm{~mm})$ that occurred in GC5. In this way, the nitrogen fertilization and residual effect of the previous cycle stimulated growth, and stress factors activated the secondary metabolism for the formation of lignin to grass (Tables 1 and 4) and consequently interfered with the decreased digestibility DM, OM and NDF in GC6 (Table 5).

The physical structures of the grass changed according to the weather conditions and were reflected in the leaf digestibility values. Van Soest (1994) reported that at high temperatures, tropical grasses have greater disparity in quality among plant parts. Moreover, the quality of the leaf decreases due to lignifications to the midrib, which contain a major portion of the lignin in grass leaves. Dove (1996) reported that the increased bonding between cellulose and lignin is essential for plant strength and physical resistance. Therefore, for ruminants, this physical resistance represents the major constraint to chewing, rumination, microbial colonization and digestion.

In general, there was a linear effect, with the grass quality improving, as evidenced by both the chemical composition and the IVDMD, IVOMD and NDFD indexes with the application of $\mathrm{N}$ (Table 5).

The average of the highest points of maximum digestibility in GC4, by the quadratic effect, to reach the best digestibility improvement of DM, OM and NDF (Table 5) of hand-plucked samples was approximately $533 \mathrm{~kg} \mathrm{~N} / \mathrm{ha} / \mathrm{year}$, which coincided with the peak GDD (Fig. 2). This moment also coincided with the greatest water availability ( $394 \mathrm{~mm}$ ) and best temperatures for the growth of Xaraes palisade grass (Figs. 1 and 2).

The overall average of the maximum points that were obtained in the significant regression equations of the $\mathrm{N}$ fertilization rates to improve the digestibility of DM, OM and NDF was approximately $382 \mathrm{~kg} \mathrm{~N} / \mathrm{ha} /$ year.

In this approach, the nutritional value of tropical forages depends on the nitrogen fertilization, management strategy, type of grass, form of planting and climatic variation present in each grazing cycle. From the regressions, we found that for every $\mathrm{N}$ fertilization rate, there was a distinct pattern of GDD relationship with the productive and qualitative components Xaraes palisade grass (Table 6). These responses show that management factors and climatic conditions also govern the qualitative responses of the grass (Table 1 and Figs. 1 and 2), confirming the hypothesis that the climatic factors of each grazing cycle, combined with the nitrogen fertilization rate, may accelerate the maturity of the plant, which in turn may affect the quality of the grass. The grazing cycle accelerates plant maturity due to climate issues. Moreover, $\mathrm{N}$ fertilization accelerates grass growth, and the fibrous fraction increases proportionally to the physical structure but with increasing senescence. 
In this context, grazing management is essential for obtaining forage quality, corroborating the results obtained by Deinum and Dirven (1972) and Campos et al. (2013).

It has long been established that the response of $\mathrm{CP}$ and herbage yield, for example, to fertilizer rates exceeding $450 \mathrm{~kg} \mathrm{~N} / \mathrm{ha} /$ year, is negligible, particularly with tropical forage grasses (Vicente-Chandler et al., 1959; Johnson et al., 2001). Therefore, the results presented in this study suggest improved grass quality with high rates of nitrogen fertilization. However, this result will depend on the management strategy that is used, even under different environmental conditions. This finding is of practical importance for the management of tropical pastures for improved grass quality and indirectly increases the intake of forage, performance and animal productivity.

\section{Conclusions}

Grazing cycles combined with nitrogen fertilization affect the quality of Xaraes palisade grass, as indicated by handplucked samples, according to the climatic condition and GDD. Nitrogen fertilization increased the CP content and decreased the fibre content of the samples. $\mathrm{N}$ fertilization stimulated the formation of cell walls with better-quality fibre, which resulted in a higher forage digestibility. The average maximum potential responses of DM, MO and NDF digestibility of Xaraes palisade grass occurred at the rate of $533 \mathrm{~kg} \mathrm{~N} / \mathrm{ha} / \mathrm{year}$, which coincided with a peak GDD of 399 and the greatest water availability $(394 \mathrm{~mm})$. Greater improvements in the forage quality were obtained with $\mathrm{N}$ rates greater than $382 \mathrm{~kg} / \mathrm{ha} / \mathrm{year}$.

\section{Acknowledgements}

The authors are grateful for the financial support provided by the Department of Soils and Fertilizers, Soil Laboratory Analysis, University of São Paulo, UNESP, Jaboticabal, SP 13418.900, Brazil.

\section{References}

ANKOM Technology, 2014. Neutral detergent fiber in feeds - filter bag technique (for A200 and A200I), ANKOM.

<https://www.ankom.com/sites/default/files/document-files/Method_6_NDF_Method_A200_RevE_11_04_14.pdf>.

AOAC, 1990. Official Methods of Analysis, 15th ed. Association of Official Analytical Chemists, Arlington.

Baumont, R., Lewis, E., Delaby, L., Prache, S., Horan, B., 2014. Sustainable intensification of grass-based ruminant production. In: EGF at 50: the future of European grasslands. In: Proceedings of the 25th General Meeting of the European Grassland Federation, Aberystwyth, Wales, 7-11 September 2014 Grassl. Sci. Europe, 19, pp. 521-532.

Berndt, A., Tomkins, N.W., 2013. Measurement and mitigation of methane emissions from beef cattle in tropical grazing systems: a perspective from Australia and Brazil. Animal 7, 363-372.

Campos, F.P., Sarmento, P., Nussio, L.G., Lugão, S.M.B., Lima, C.G., 2013. Fiber monosaccharides and digestibility of Milenio grass under N fertilization. Anim. Feed Sci. Technol. 183, 17-21.

Dahiya, R., Ingwersen, J., Streck, T., 2007. The effect of mulching and tillage on the water and temperature regimes of loss water: experimental finding and modeling. Soil Tillage Res. 96, 52-63.

Deinum, B., Dirven, J.G.P., 1972. Climate, nitrogen and grass. 5. Influence of age: light intensity and temperature on the production and chemical composition of Congo grass (Brachiaria ruziziensis German et Everard). Neth. J. Agic. Sci. 20, 125-132.

Dove, H., 1996. The ruminant, the rumen and the pasture resource: nutrient interaction in the grazing animal. Chapter 8, 219-246. In: Hodson, J., Illius, A.W. (Eds.), The Ecology and Management of Grazing Systems. CAB International, Wallingford, UK, p. 466.

Dryden, G.M., 2008. Animal Nutrition Science, eight ed. CABI, Wallingford, U.K, pp. 48.

FAOSTAT, 2015. Food Agriculture Organization of the United Nations-Statistic Division. Available at: <http://faostat3.fao.org/compare/E>.

Goering, K.H., Van Soest, P.J., 1970. Forage fiber analysis (apparatus, reagents, procedures, and some application). In: USDA Agricultural Handbook. ARS-USDA, Washington, pp. 379.

Hughes, M., Mlambo, V., Jennings, P.G.A., Lallo, C.H.O., 2014. The accuracy of predicting in vitro ruminal organic matter digestibility from chemical components of tropical pastures varies with season and harvesting method. Trop. Agric. 91, 131-146.

Johnson, C.R., Reiling, B.A., Mislevy, P., Hall, M.B., 2001. Effects of nitrogen fertilization and harvest date on yield digestibility, fiber, and protein fractions of tropical grasses. J. Anim. Sci. 79, 2439-2448.

Larch, W., 2004. Ecofisiologia Vegetal. Rima Artes e Textos, São Carlos, SP, Brazil, pp. 531.

Larch, W., 1994. Ökophysiologie der Pflanzen. Ulmer GmbH \& Co., Stuttgart, Germany (Original).

Lara, M.A.S., 2011. Respostas morfofisiológicas de genótipos de Brachiaria spp. sob duas intensidades de desfolhação e modelagem da produção de forragem em função das variações estacionais da temperatura: adaptação do modelo CROPGRO, Piracicaba, SP, Brazil. 112p, Tese (Doutorado)-Escola Superior de Agricultura Luiz de Queiroz, Universidade de São Paulo. Available at: <http://www.teses.usp.br/teses/disponiveis/11/11139/tde-24052011-093743/en.php> (Eng. Abstr. and p.141 and p.154).

Minson, D.J., Milford, R., 1967. The voluntary intake and digestibility of diets containing different proportions of legume and mature Pangola grass (Digitaria decumbens). Aust. J. Exp. Agric. Anim. Husb. 7, 546-551.

Nave, R.L.G., Pedreira, C.G.S., Pedreira, B.C., 2010. Nutritive value and physical of Xaraes palisadegrass as affected by grazing strategy. S. Afr. J. Anim. Sci. 40, 285-293.

Pedreira, B.C., Pedreira, C.G.S., 2007. Leaf photosynthesis in Xaraes palisadegrass [Brachiaria brizantha (A. Rich.) Staf. Cv. Xaraes] and modeling canopy assimilatory potential under rotational stocking strategies. R. Bras. Zootec. 36, 773-779 (Eng. Abstr.).

Pedreira, B.C., Pedreira, C.G.S., Silva, S.C., 2009. Herbage accumulation during regrowth of Xaraes palisadegrass submitted to rotational stocking strategies. R. Bras. Zootec. 38, 618-625 (Eng. Abstr.).

Pequeno, D.N.L., Pedreira, C.G.S., Sollenberger, L.E., Faria, A.F.G., Silva, L., 2015. Forage accumulation and nutritive value of Brachiariagrasses and Tifton 85 Bermudagrass as affected by harvest frequency and irrigation. Agron. J. 107, 1741-1749.

Pessarakli, M., 2014. Advance of common bean and Brachiaria to abiotic stresses- adaptation of Brachiaria forage grasses to abiotic constraints. Chapter 39, 863-889. In: Handbook of Plant and Crop Physiology, Third ed. CCR-Press, pp. 962.

Peters, M., Herrero, M., Fisher, M., Erb, K.H., Rao, I., Subbarao, G.V., Castro, A., Arango, J., Chará, J., Murgueitio, E., Hoek, R.V.D., Läderach, P., Hyman, G., Tapasco, J., Strassburg, B., Paul, B., Rincón, A., Kraft, R.S., Fonte, S., Searchinger, T., 2013. Challenges and opportunities eco-efficiency of tropical forage-based systems to mitigate greenhouse gas emissions. Trop. Grassl. For. Trop. 1, 156-167.

Poppi, D.P., McLennan, S.R., 1995. Protein and energy utilization by ruminants at pasture. J. Anim. Sci. 73, 278-290. 
Robertson, J.B., Van Soest, P.J., 1981. The detergent system of analysis. In: James, W.P.T., Theander, O. (Eds.), The Analysis of Dietary Fiber in Food, 123. Marcel Dekker, NY and Basel, p. 158, Chapter 9.

Rolim, G.S., Sentelhas, P.C., Barbieri, V., 1998. Planilhas no ambiente Excel ${ }^{\mathrm{TM}}$ para os cálculos de balanços hídricos: normal, seqüencial, de cultura e de produtividade real e seqüencial. Rev. Bras. Agromet. 6, 133-137 (Eng. Abstr.).

Santos T. M., 2010. Respostas morfológicas e produtivas do capim-xaraés, sob pastejo, à adubação nitrogenada. 2010. 49p. Dissertação (mestrado)-Universidade Estadual Paulista, Faculdade de Ciências Agrárias e Veterinárias, 2010. Available at: <http://hdl.handle.net/11449/88309>, (Eng. Abstr.).

SAS INSTITUTE Inc. SAS/STAT, 2003. User's Guide, Version 9.1. SAS Institute, Cary.

Silva, E.A., Silva, W.J., Barreto, A.C., Junior, A.B.O., Paes, J.M.V., Ruas, J.R.M., Queiros, D.S., 2012. Chemical composition and photosynthetically active radiation of forage grasses under irrigation. R. Bras. Zootec. 41, 583-591.

Silveira, C.P., Nachtigall, G.R., Monteiro, F.A., 2005. Testing and validation of methods for the diagnosis and recommendation integrated system for signal grass. Sci. Agric. (Piracicaba, Braz.) 62, 520-527.

Sinclair, T.R., Selligman, N.G., 1995. Global environment change and simulated forage quality of wheat: I. Nonstressed conditions. Field Crops Res. 40, $19-27$.

Sniffen, C.J., O’Connor, J.D., Van Soest, P.J., Fox, D.G., Russel, J.B., 1992. A net carbohydrate and protein availability. J. Animal Sci. $70,3562-3577$.

Sollenberger, L.C., Cherney, D.J.R., 1995. Evaluation Forage Production and Quality: the Science Grassland Agriculture. State University Press, Ames, Iowa, pp. 97-110.

Trenholm, L.E., Dudeck, A.E., Sartain, J.B., Cisar, J.L., 1998. Bermudagrass growth, total nonstructural carbohydrate concentration, and quality as influenced by nitrogen and potassium. Crop Sci. 38, 168-174.

Thornthwaite, C.W., Mather, J.R., 1957. Instructions and tables for computing potential evapotranspiration and water balance. Public Clim. 10, 181-311.

Valle, C.B., Euclides, V.P.B., Macedo, M.C.M., Valério, J.R., Calixto, S., 2001. Selecting new brachiaria for Brazilian pastures. In: Proceedings of the XIX International Grassland Congress - Grassland Ecosystems - An outlook into the 21st Century-11 a 21/02/2001, Sao Pedro, Sao Paulo, Brazil, pp. 13-14.

Van Soest, P.J., 1967. Development of a comprehensive system of feed analyses and its application to forages. J. Anim. Sci. $26,119-128$.

Van Soest, P.J., Robertson, J.B., Lewis, B.A., 1991. Methods for dietary fiber, neutral detergent fiber, and nonstarch polysaccharides in relation to animal nutrition. J. Dairy Sci. 74, 3583-3597.

Van Soest, P.J., 1994. Nutritional Ecology of the Ruminant, 2nd ed. Cornell University Press, Ithaca, pp. 476 (Chapter 11-Carbohydrates, pp 150 and 169).

Vendramini, J.M.B., Sollenberger, L.E., Soares, A.B., Silva, W.L., Sanchez, J.M.D., Valente, A.L., Aguiar, A.D., Mullenix, M.K., 2014. Harvest frequency affects herbage accumulation and nutritive value of Brachiaria grass hybrids in Florida. Trop. Grassl. - For. Trop. 2, $197-206$.

Vicente-Chandler, J., Silva, S., Figarella, J., 1959. The effects of nitrogen fertilization and frequency of cutting on the yield and composition of three tropical grasses. Agron. J. 51, 202-206

Wiles, P.G., Gray, I.K., Kissling, R.C., 1998. Routine analysis of protein by Kjeldahl and Dumas methods: review and interlaboratory study using dairy products. J. AOAC Int. 81, 620-632

Wilson, J.R., 1976. Variation of leaf characteristics with level of insertion on a grass tiller. II. Anatomy. Austr. J. Agric. Res. $27,355-364$.

Wilson, J.R., 't Mannetje, L., 1978. Senescence: digestibility and carbohydrate content of Buffel grass and green panic leaves in swards. Aust. J. Agric. Res. $29,503-516$ 